\title{
ガスクロマトグラフィーおよび質量スペク トルによる共重合体の熱分解分析
}

神 戸 博 太 郎*

\section{1. は じめに}

2 種のモノマーを共重合させたとき，果して共重合し ているかどらか，いいか党れば得られた重合体が 2 種の ホモポリマーの混合物ではないだららかという疑問は常 に起こる。この場合溶解度の差によって分別が可能なら ば，分別区分の組成を化学的手段により分析してみるこ とが，共重合の確認の方法としてもっとも確実である。

分析の手段としては通常の元素分析炕よることもよい が，特代識別しやすい元素を含むモノマーが関与してい ない限り，むしろ機器分析䢍が工合がよい。この 特集の別の項飞述べられているIR，NMR とよること も可能であるが，ここではそれ以外の有力な手段として， ガスクロマトグラフィー（以下ガスクロと略す）扰よび 質量分析を用いる方法を述べる。

\section{2. 共重合体の組成と連鎖分布}

本論に入る前問題の所在を明らかにして叔こう。話 を簡単にするために，A，B 2 種のモノマーからなる鎖 状の共重合体を考党る。共重合体を特徵ずけるのはその 分子量と組成（モル分率 $F_{1} ， F_{2}$ ) であるが，一般に分 子量に分布があると同様に，組成に分分布があるから， 分析によって求められるのは平均組成である。

組成分布を孔つ共重合体を溶解再沈によって, 組成の 均一な区分に分別することは，分子量の差による分別効 果と区別できないので，実際には行なわれない。しかし 後に述べるよらた，たとえばビニルモノマーのラジカル 共重合では反応初期には仕込みのモノマー比によってき まる浮ぼ一定の組成をもつ共重合体が得られるので，低 重合率に抑兄机涪組成分布のあ委り大きくない試料をつ くることができる。また組成分布のある試料では光散乱 法で求めた見か壮の重量平均分子量が溶媒 (の屈折率) 飞依存するのでここれよって組成の均一であるか否か を判定することができる。

さらに共重合体の場合には組成が均一でも，A，B両

* Hirotaro KAMBE 東京大学教授・理博

Pyrolytic Analysis of the Copolymer by Gas

Chromatography and Mass Spectroscopy
モノマーの配列のしかたに分布がある。これを連鎖分布 (sequence distribution) 乙呼ぶ。基本的な型としては

$$
\begin{aligned}
& \text { ランダム (random) ABAABBBAAB } \\
& \text { 交互性 (alternating) } \mathrm{ABABABABAB}
\end{aligned}
$$

ブロック (block) AAAAABBBBB

がある。ブロック共重合体嗵常Aのホモポリマーの先 にBを重合させてつくるのであるから特殊である。しか 乙2種のホモポりマーの混合物との相異を求めることは 興味がある。2 種のビニルモノマーの混合物を重合させ たとき，ランダムになるか，交互性になるかはモノマー の組合好子重合条件炕よってきまる。一般にはランダム と交互性の中間のものができる。これらの生成を説明す るラジカル共重合の理論は，モノマーの混合の割合（モ 几分率 $f_{1}, f_{2}$ ) 種々の重合率 (conversion) 飞拈ける生 成した共重合体の組成および連鑜分布の関係を与兄る。 したがって共重合体の組成和よび連鑽分布の決定は, 単 にその共重合体の特徴付访 (characterization)のみな らず，共重合の理論の裏付けを与学るためにも重要であ る。

連鎖分布と組成とは，互に関連をもっている。完全に 交互性の場合には組成は $F_{1}=F_{2}=0.5$ となる。ランダ ムとブロックでは任意の組成をとることができるが，連 鎖分布はブロックでは一通りしがいいが，ランダムでは 長さの異なる連鎖が統計的な法則に従い,でたらめに分 布している。

連鎖分布は鎖状共重合体の分子飞执いて，同一モノマ 一単位がつづいてならんだ連鎖 (sequence または run) の分布を意味している1)。たと党ば A，B モノマー単位 からなる共重合体

$$
\begin{aligned}
\sim-A-B & -A-A-B-B-A-B-A-A- \\
-B-A-B-B-B-A-A-A-B-B & =
\end{aligned}
$$

に打いて，下に引いた線が連鎖を示ず。HarwoodRitchey ${ }^{2)}$ は 100 モノマー単位またりの連鎖の平均数を 連鎖数 (run number) と呼び， $R$ で示した。上の例で は 20 単位に刘して連鎖が 12 個あるから， $R=60$ であ る。 $R$ を用いて共重合体の組成步よび渾鎖分布を次の上 うに表現することができる。 
共重合体の組成（モル分率）を A，Bに対してそれぞ れ $F_{1} ， F_{2}$ とすれば，100モノマー単位中に含まれる $\mathrm{A}, \mathrm{B}$ 単位の数は $100 F_{1}, 100 F_{2}$ に等しい。100 単位 中に含まれる $\mathrm{A}$ 連鎖， $\mathrm{B}$ 連鎖の平均数は等しく, その和 壮 $R$ であるから，それぞれ $R / 2$ 個ずつ存在する。ゆえ に A 連鎖, $\mathrm{B}$ 連鎖の数平均連鎖長は

$$
\begin{aligned}
& <L_{1}>=\frac{100 F_{1}}{R / 2} \\
& <L_{2}>=\frac{100 F_{2}}{R / 2}
\end{aligned}
$$

となる。

共重合体の分析の結果, 分子中に含まれる全結合の中 A-A，B-B 特よび A-B (B-A を含む) 結合の割合が定 められる。A連鎖の後には必ず $\mathrm{B}$ 連鎖, 逆にB連鎖の後 にをは必ず $\mathrm{A}$ 連鎖が続くから, 100 単位あたり異種結合 $\mathrm{A}-\mathrm{B}$ および $\mathrm{B}-\mathrm{A}$ 結合の数は $\mathrm{A}$ および $\mathrm{B}$ 連鎖の数 $R / 2$ に等しい。100 単位あたり $\mathrm{A}$ 打よび $\mathrm{B}$ 単位の数は $100 F_{1}, 100 F_{2}$ であるから, 同稞結合 $\mathrm{A}-\mathrm{A}$ 扎よび B-B 結合の数は， $\left(100 F_{1}-R / 2\right),\left(100 F_{2}-R / 2\right)$ となる。

したがって A-A, B-B, A-B, B-A 結合のできる確 率を $P_{11}, P_{22}, P_{12}, P_{21}$ とすれば

$$
\begin{aligned}
P_{11} & =\frac{100 F_{1}-R / 2}{100 F_{1}} \\
P_{12} & =\frac{R / 2}{100 F_{1}} \\
P_{22} & =\frac{100 F_{2}-R / 2}{100 F_{2}} \\
P_{21} & =\frac{R / 2}{100 F_{2}}
\end{aligned}
$$

で表わされる*1。Rはこれらの確率と組成から決定でき る。

Rは連鎖分布の型によってその值がきまる。ブロック の場合は最も小さいが，その值は重合度により異なる。 交互性の場合は最大で $R=100$ である。ラジカル重合に よって生ずるビニル共重合体では，モノマー単位は統計 的火分布するので， $R$ は理論的に求められる。

共重合理論によれば，生長反応の停止が問題にならな い初期段階飞和いて, モノマーの反応性比を $r_{1}=k_{11} / k_{12}$, $r_{2}=k_{22} / k_{21}$ として統計的共重合体の組成とモノマーの仕 込濃度との関係は

$$
\begin{aligned}
& F_{1}=\frac{r_{1} f_{1}^{2}+f_{1} f_{2}}{r_{1} f_{1}^{2}+2 f_{1} f_{2}+r_{2} f_{2}^{2}} \\
& F_{2}=\frac{r_{2} f_{2}^{2}+f_{1} f_{2}}{r_{1} f_{1}^{2}+2 f_{1} f_{2}+r_{2} f_{2}^{2}}
\end{aligned}
$$

柰た A-A， A-B，B-B，B-A 結合の生ずる確率は

*1 Harwood は $P_{12}$ 呿よび $P_{21}$ の定義を引つのモ， マー単位が並んだとき，爷れぞれ中心のA の右ま たは左にBがくる磪率，特よび中心のBの右また は左汇 A がくる確率としている。

$$
\begin{aligned}
& P_{11}=\frac{r_{1} f_{1}}{r_{1} f_{1}+f_{2}} \\
& P_{12}=\frac{f_{2}}{r_{1} f_{1}+f_{2}} \\
& P_{22}=\frac{r_{2} f_{2}}{f_{1}+r_{2} f_{2}} \\
& P_{21}=\frac{f_{1}}{f_{1}+r_{2} f_{2}}
\end{aligned}
$$

で表わされる。これらの式は縪密には反応の開始期の瞬 間モノマー濃度 $f_{1}, f_{2}$ に対して適用されるもので，共 重合の進行とともに残存モノマー濃度 $f_{1}, f_{2}$ が变化す るから, 共重合体の組成 $F_{1}, F_{2}$ もこれに伴って時間と ともに变化する。けれども奏際には反応の初期にはモ， マーが多量にあるので $f_{1}, f_{2}$ の時間的変化はわずかで あり，したがって $F_{1} ， F_{2}$ もあまり变らないと考えてよ い。そこで少なくとも重合率を 10\% 以下くらいに抑兑 れば，得られた共重合体の組成は初めのモノマー仕达み 濃度を用いて上の式によって近似的に計算される。

(2)，(4) 式の $P_{12}$ は同じ女のを表わしているから， これらを等しいとおき，(3) 式の $F_{1}$ を用いれば，統計 的共重合体に対して

$$
R=\frac{200}{r_{1}\left(f_{1} / f_{2}\right)+2+r_{2}\left(f_{2} / f_{1}\right)}
$$

が得られる。もちろん $P_{21}$ からも同じ式が導かれる。

同椂にして penultimate 効果を考慮した場合には, モ ノマ一の反応性比を

$$
r_{1}=\frac{k_{111}}{\dot{k}_{112}}, \quad r_{1}^{\prime}=\frac{k_{211}}{k_{212}}, \quad r_{2}=\frac{k_{222}}{k_{221}}, \quad r_{2}{ }^{\prime}=\frac{k_{122}}{k_{121}}
$$

とすれば

$$
R=\frac{200}{\frac{1+r_{1}\left(f_{1} / f_{2}\right)}{1+\left(1 / r_{1}{ }^{\prime}\right)\left(f_{2} / f_{1}\right)}+2+\frac{1+r_{2}\left(f_{2} / f_{1}\right)}{1+\left(1 / r_{2}{ }^{\prime}\right)\left(f_{1} / f_{2}\right)}}
$$

となる2)。

これらの式によれば，共重合の反応性比が与党られて いるときには $f_{1}, f_{2}$ によって $R$ が定孪る。逆に種々の $f_{1}, f_{2}$ に効して生じた共重合体の組成と連鎖分布を分析 して（2）式を用いて $R$ 孛定めれば，反応性比が決定で きる。

一般の共重合体で奏测した $R$ が，（5）式を用いて計 算した值より大きけ机ば統計的共重合体よりも交互性が よく，逆に小さけ机ばブロック性が大きいことになる。 完全にランダムな連鎖分布をるつ場合 $\left(r_{1} r_{2}=1\right)$ には

(5) 式より

$$
R=\frac{200}{r_{1}\left(f_{1} / f_{2}\right)+2+\left\{1 / r_{1}\left(f_{1} / f_{2}\right)\right\}}
$$

一方 (3) 式より

$$
\begin{aligned}
& F_{1}=\frac{r_{1}\left(f_{1} / f_{2}\right)+1}{r_{1}\left(f_{1} / f_{2}\right)+2+\left\{1 / r_{1}\left(f_{1} / f_{2}\right)\right\}} \\
& F_{2}=\frac{\left\{1 / r_{1}\left(f_{1} / f_{2}\right)\right\}+1}{r_{1}\left(f_{1} / f_{2}\right)+2+\left\{1 / r_{1}\left(f_{1} / f_{2}\right)\right\}}
\end{aligned}
$$


ゆ完に

$$
R=200 F_{1} F_{2}=\frac{\left(100 F_{1}\right)\left(100 F_{2}\right)}{50}
$$

となる。重縮合によって生ずる完全ランダム共重合体に 物いても，Rはこの值をとる。

五十嵐 ${ }^{3)}$ 《連鎖分布之組成之の関係老三角座標を用い て図示する方法を考案した。共重合体分子中に存在する 全モノマー単位の中で A-A，B-B，A-B（抢よび B-A) 結合をつくっているすのの割合 (モル分率)を炎机皆机 $X, Y, Z$ とすると

$$
\begin{aligned}
& X=P_{11} F_{1} \\
& Y=P_{22} F_{2} \\
& Z=1-X-Y=\left(1-P_{11}\right) F_{1}+\left(1-P_{22}\right) F_{2}
\end{aligned}
$$

で表わされる。とれらを（2）式と比べれば

$$
\begin{aligned}
& X=F_{1}-\frac{R}{200} \\
& Y=F_{2}-\frac{R}{200} \\
& Z=\frac{R}{100}
\end{aligned}
$$

であることがわかり，Zはモル分率で表わした連鎖数に 相当する。

統計的共重合体の場合飞は（3）武妾 $r_{1}\left(f_{1} / f_{2}\right)$ 掠よ び $r_{2}\left(f_{2} / f_{1}\right)$ について解き，(4) 式の $P_{11}, P_{22}$ に代入 して, $X, Y, Z$ 存 $F_{1}, F_{2}$ で表わせば

$$
\begin{aligned}
& X=F_{1}-\frac{2 F_{1} F_{2}}{1+\sqrt{D}} \\
& Y=F_{2}-\frac{2 F_{1} F_{2}}{1+\sqrt{D}} \\
& Z=\frac{4 F_{1} F_{2}}{1+\sqrt{D}}
\end{aligned}
$$

となる。ただし

$$
D=\left(F_{1}-F_{2}\right)^{2}+4 r_{1} r_{2} F_{1} F_{2}
$$

である。

完全にランダム交場合 $\left(r_{1} r_{2}=1\right)$ Kは $D=\left(F_{1}+F_{2}\right)^{2}=1$ であるから

$$
X=F_{1}^{2}, \quad Y=F_{2}^{2}, \quad Z=2 F_{1} F_{2}
$$

となる。(11) 式の $Z$ を（9）式と此べて，同じく（7） 式の $R$ が得られる。

そこで共重合体の組成 $F_{1}, F_{2}$ が求められ，反応性比 の積 $r_{1} r_{2}$ の值がわかっていれば，(10）式を用いて，共 重合体中の結合の存在する割合を $X, Y, Z$ の三角座標 で表わすことができる。の图の例は後に示す(第 6 図) が, 三角形の二つの頂点は A, B 両小モポりマーを, 第3 の頂点は完全飞交互性の共重合体表表わしている。 組成は $\mathrm{A}-\mathrm{B}$ 軸上の目盛で表わされ， $\mathrm{AB}$ 軸上に近いと ころではブロック性がよく，A，B軸から遠ざかるほど 交互性の良い，すなわち（9）式の示すよう連鎤数 $R$ が大きいことが示される。

\section{3. 共重合体の熱分解}

以上述べたように，共重合体の連鎖分布を表わす $R$ または $Z$ を決定与るには，A，B 両成分の組成（モル 分獄）批よび $\mathrm{A}-\mathrm{A}, \mathrm{B}-\mathrm{B}, \mathrm{A}-\mathrm{B}$ (特よび $\mathrm{B}-\mathrm{A}$ ) 結合の 存在率 (モル分率) を決定することが必要である。IR や NMR 学用いるときには共重合体陚料そのま河つ いて測定が行な党るが，化学分析栾たはその他の機器分 析に戈いては，共重合体を分解して生成物を調べなけれ ばならない。分解の法としては酸化分解，醏素分解， 加水分解などる用いられるが1)，ここでは主として熱分 解に上る方法を述べる。

共重合体の熱分解生成物の中からはしばしばそのモ， マーが検出される。特にいわ切る解重合 (depolymerization）を行なら場合には多量のモ/マーが生成する。主 鎖がでたらめの長さに切れるランダム分解や，側鎖によ る環化承たは他の鎖との間に橋がけを起こす場合にはモ ノマーの生成量が少ない。このようとモノマーの生成量 から熱分解の機構を推定することがでさる。しかも共重 合体の熱分解による成分も, マーの回収率 $Y$ は，一般 にホモポリマーからの回収率 $Y_{0}$ と異なる。この比 $Y / Y_{0}$ を相対モノマー収量 (relative monomer yield) と呼ぶ。 Wa11 ${ }^{4)}$ はこの值と共重合体の組成との間に次のような 関係劣導いた。

成分モノマーK初めから存在していた C-C 結合を内 部結合（internal bond），重合によってモノマー間飞新 しく形成された C-C 結合を外部結合(external bond) と 乎ぶ。共重合体の熱分解により，内部結合が切れれば， 仕込んだモノマーと異なる構造のモノマーが生成する可 能性がある。したがって，元のモノマーが回収できなく なる割合を次のパラメーターで表わす。

$$
\theta=2 \frac{\text { 切れた内部結合の数 }}{\text { 共重合体に存在した内部結合の総数 }}
$$

熱分解以より完全に元のモノマーに分解する場合には $\theta$ $=0$ 内部結合だげが切れるので $\theta=2$ の値をとる。ラン ダム分解のとさとは，内部蛙上び外部結合が同じ確率で 切れるので $\theta=1$ となる。たと光ば $\mathrm{CH}_{2}=\mathrm{CHX}$ と $\mathrm{CHY}$ $=\mathrm{CHY}$ とが結合してつくる次の共重合体沈いて

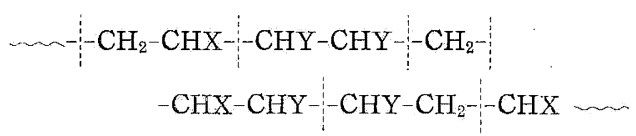

外部結合の切断飞よる元のモ, マー $\mathrm{CH}_{2}=\mathrm{CHX}$,

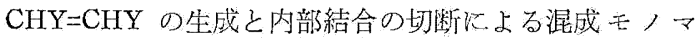
- (hybrid mononer) $\mathrm{CHX}=\mathrm{CHY}$ 扩よび $\mathrm{CHY}=\mathrm{CH}_{2}$ の生成とほ全く同じ確率で行なわ㧈るので，4種のモ， マーが同量ずつ生成する。ゆ光に $\theta=1$ となる。

$\mathrm{CH}_{2}=\mathrm{CHX}$ 牥よび $\mathrm{CH}_{2}=\mathrm{CHY}$ からなるビニル型共重 合体では内部結合が切れたか，外部結合が切れたが $\left(\mathrm{CH}_{2}\right.$ の $\mathrm{C}$ 原子を放射性同位元素で祘きかえなければ） 
判定できない。

一般に共重合体は多少とも連鎖分布をるつ，その分解 も必ずしもランダム分解ではない。モノマーAの $i$ 個の 連鎖があるとき, 分解して混成モノマーを生じ, 元のモ ノマーの回収率を下げ， $\theta$ を大さくするのは，軽鎖の境 界のすぐ内側の内部結合が切れる場合である。

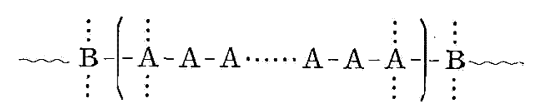

したがって共重合体の交互性が良く，連鎖の境界の数が

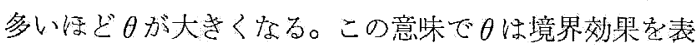
わすパラメーターとみなさ就る。

共重合体の一つのB単位につづいて $i$ 個のA単位から なる連鎖の生ずる確率は

$$
P_{i}(\mathrm{~A})=P_{21} P_{11}^{i-1} P_{12}
$$

で与えられる。 $P_{11}, P_{12}, P_{21}$ は一般には（2）式で，統 棓的共重合体の場合には（4）式で示される。（12）式よ 门)

$$
\begin{aligned}
\sum_{i=1}^{\infty} P_{i}(\mathrm{~A})= & P_{21} \sum P_{11}{ }^{i-1}\left(1-P_{11}\right)= \\
& P_{21}\left(\sum P_{11}{ }^{i-1}-\sum P_{11}{ }^{i}\right)=P_{21}
\end{aligned}
$$

である。 $P_{21}$ は B-A 結合のできる確率であるから，

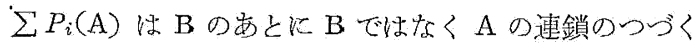
確率芝表わしている。

$\mathrm{B}$ の組成（モル分率）は $F_{2}$ でするから，共重合体の 中で B の後につづく $i$ 個の連鎖の割合 (モル分率) は $F_{2} P_{i}(\mathrm{~A})$ となる。したがって A の組成は

$$
F_{1}=\sum_{i=1}^{\infty} i F_{2} P_{i}(\mathrm{~A})=F_{2} \sum i P_{i}(\mathrm{~A})
$$

で表わされる。

ところで $i$ 個のモノマー単位からなるAのホモポリマ 一加らのAモノマ一の回収率を $Y_{0}(\mathrm{~A})$ と寸る。一方共 重合体中の $i$ 個からなるA連鎖からある一つのAモノ、 一の回収される確率は， $i$ 個の内部結合の中 $\theta_{1} / 2$ 個が 切机るから， $\left(i-\left(\theta_{1} / 2\right) / i\right)$ で表わされる。したがって共 重合体からのAモノ水回収率は

$$
Y(\mathrm{~A})=Y_{0}(\mathrm{~A}) \sum_{i=1}^{\infty} i F_{2} P_{i}(\mathrm{~A}) \frac{i-\theta_{1} / 2}{i}
$$

となる。ゆ光に相対モノマー収量は（12），(13）

式老用いて

$$
\begin{aligned}
\frac{Y(\mathrm{~A})}{Y_{0}(\mathrm{~A})} & =\sum i F_{2} P_{i}(\mathrm{~A})-\frac{\theta_{1}}{2} F_{2} \sum P_{i}(\mathrm{~A}) \\
& =F_{1}-\frac{\theta_{1}}{2} F_{2} P_{21}=F_{1}-\frac{R}{400} \theta_{1}
\end{aligned}
$$

で与えられる。

同様にして B モノマーの相対収量は

$$
\frac{Y(\mathrm{~B})}{Y_{0}(\mathrm{~B})}=F_{2}-\frac{\theta_{2}}{2} F_{1} P_{12}=F_{2}-\frac{R}{400} \theta_{2}
$$

Vol. 15, No. 169
となる。組成 $F_{1}, F_{2}$ のモノマー単位の中間部結合が切 れたため混成モノマーとして回収された部分の相対モノ マー収量は

$$
\frac{Y^{\prime}(\mathrm{A})}{Y_{0}^{\prime}(\mathrm{A})}=F_{1}-\frac{Y(\mathrm{~A})}{Y_{0}(\mathrm{~A})}=\frac{\theta_{1}{ }^{\prime}}{2} F_{2} P_{21}=\frac{R}{400} \theta_{1}{ }^{\prime}
$$

抌よび

$$
\frac{Y^{\prime}(\mathrm{B})}{Y_{0}^{\prime}(\mathrm{B})}=F_{2}-\frac{Y(\mathrm{~B})}{Y_{0}(\mathrm{~B})}=\frac{\theta_{2}{ }^{\prime}}{2} F_{1} P_{12}=\frac{R}{400} \theta_{2}{ }^{\prime}
$$

と市る。

統計的共重合体の場合には（3），(4) 式を用いて

$$
\begin{aligned}
\frac{Y(\mathrm{~A})}{Y_{0}(\mathrm{~A})} & =F_{1}\left(1-\frac{\theta_{1}}{2} \cdot \frac{f_{2}}{r_{1} f_{1}+f_{2}}\right) \\
\frac{Y(\mathrm{~B})}{Y_{0}(\mathrm{~B})} & =F_{2}\left(1-\frac{\theta_{2}}{2} \cdot \frac{f_{1}}{f_{1}+r_{2} f_{2}}\right) \\
\frac{Y^{\prime}(\mathrm{A})}{Y_{0}^{\prime}(\mathrm{A})} & =F_{1} \frac{\theta_{1}}{2} \cdot \frac{f_{2}}{r_{1} f_{1}+f_{2}} \\
& =\frac{\theta_{1}^{\prime}}{2} \cdot \frac{f_{1} f_{2}}{r_{1}} \frac{f_{1}^{2}+2 f_{1} f_{2}+r_{2} f_{2}^{2}}{Y^{\prime}(\mathrm{B})} \\
Y_{0}^{\prime}(\mathrm{B}) & =F_{2} \frac{\theta_{2}^{\prime}}{2} \cdot \frac{f_{1}}{f_{1}+r_{2} f_{2}} \\
& =\frac{\theta_{2}{ }^{\prime}}{2} \cdot \frac{f_{1} f_{2}}{r_{1} f_{1}^{2}+2 f_{1} f_{2}+r_{2} f_{2}^{2}}
\end{aligned}
$$

で与完られる。

$\theta_{1}{ }^{\prime}=\theta_{2}{ }^{\prime}$ ならば $\left(15^{\prime}\right),\left(16^{\prime}\right)$ 式より $Y^{\prime}(\mathrm{A}) / Y_{0}{ }^{\prime}(\mathrm{A})=$

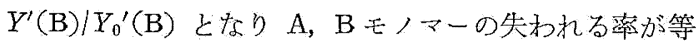
しい。なた (15)，(16) 式より外部結合だけが切れる場合 $\left(\theta_{1}=\theta_{2}=0\right)$ k山, $Y(\mathrm{~A})=Y_{0}(\mathrm{~A}) F_{1}, \quad Y(\mathrm{~B})=Y_{0}(\mathrm{~B}) F_{2}$ となり,ホモポリマーと同じ率でモノマーが回收され る。内部結合だけが切れる場合 $\left(\theta_{1}=\theta_{2}=2\right)$ には $Y(\mathrm{~A})$ $/ Y_{0}(\mathrm{~A})=F_{1}-F_{2} P_{21}, \quad Y(\mathrm{~B}) / Y_{0}(\mathrm{~B})=F_{2}-F_{1} P_{12}$ となり， $\mathrm{A}, \mathrm{B}$ の連鎖あたり 1 個ずつのモノマーが回収されない。 ランダム分解のとき $\left(\theta_{1}=\theta_{2}=1\right)$ に恪各連鎖から $1 / 2$ 個 のモノマーが失われる。そこで一般に連鎖あたり $\theta / 2$ 個 のモノマーが失われることになる。

統計的共重合体の場合， A, B モノマ一の失われる率 は仕込みのモノマーの $f_{1}, f_{2}$ 执よび反応性化 $r_{1}, r_{2}$ に よって異なる。(17) 式より $Y^{\prime}(\mathrm{A}) / Y_{0}^{\prime}(\mathrm{A})$ 特よび $Y^{\prime}(\mathrm{B})$ $/ Y_{0}^{\prime}(\mathrm{B})$ の最大となるのは $f_{1} / f_{2}=\left(r_{2} / r_{1}\right)^{1 / 2}$ のときで, (3) 式より $F_{1}=F_{2}=1 / 2$ ，すなわち $\mathrm{A}, \mathrm{B}$ の組成の等し いときである。このとき

$$
\begin{aligned}
& Y^{\prime}(\mathrm{A}) / Y_{0}^{\prime}(\mathrm{A})=\theta_{1}{ }^{\prime} / 4\left[1+\left(r_{1} r_{2}\right)^{1 / 2}\right] \\
& Y^{\prime}(\mathrm{B}) / Y_{0}^{\prime}(\mathrm{B})=\theta_{2}{ }^{\prime} / 4\left[1+\left(r_{1} r_{2}\right)^{1 / 2}\right]
\end{aligned}
$$

となる。さらに完全交互性 $\left(r_{1} r_{2}=0\right)$ のとさ，これらは 最大値 $\theta_{1}{ }^{\prime} / 4, \theta_{2}{ }^{\prime} / 4$ をとる。

熱分解の場合にホモポリマーといえども必ずしも完全 にモノマーに分解するわけでははない。むしろある場合 には共重合体の方がモノマーになりや寸いこともある。 このよらなときには $\theta<0$ となる。

$\mathrm{A}$ 連鎖の平均連鎖長は（13），(14）式を用いて 


$$
\begin{aligned}
<L_{1}> & =\frac{\sum_{i=1}^{\infty} i F_{2} P_{i}(\mathrm{~A})}{\sum_{i=1}^{\infty} F_{2} P_{i}(\mathrm{~A})}=\frac{\sum i P_{i}}{\sum P_{i}} \\
& =\frac{F_{1} / F_{2}}{P_{21}}=\frac{1}{1-P_{11}}=\frac{1}{P_{12}}
\end{aligned}
$$

同様に

$$
<L_{2}>=\frac{F_{2} / F_{1}}{P_{12}}=\frac{1}{1-P_{22}}=\frac{1}{P_{21}}
$$

ゆ光に $\left(15^{\prime}\right)$ 式と比べて

$$
<L_{1}>=\frac{F_{1}\left(\theta_{1}^{\prime} / 2\right)}{Y^{\prime}(\mathrm{A}) / Y_{0}^{\prime}(\mathrm{A})}
$$

同様以

$$
<L_{2}>=\frac{F_{2}\left(\theta_{2}^{\prime} / 2\right)}{Y^{\prime}(\mathrm{B}) / Y_{0}^{\prime}(\mathrm{B})}
$$

(15) (16') 式に示したように, 相対毛ノマー収量と組 成，連鎖分布を表わすパラメーター $R$ とがわかれば $\theta_{1}, \theta_{2}$ が決定できる。

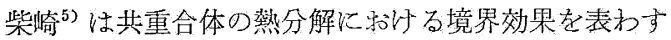
ために別のパラメーターを譐入した。ビニル共重合体の ように解重合を起こするのを考克, 束端ラジカルからモ ノマーAが脱離するとき, 隣りに同種のモノマー単位 $\mathrm{A}$ があるときの脱離の確率 $P_{\mathrm{AA}}$ は一般に隣りに異種のモ ノマー単位 $\mathrm{B} か ゙$ るときの $P_{\mathrm{AB}}$ と異なるものと考穴ら れる。そこでA単位の隣りにB単位がきたためた末端の Aがモノマーとして脱離しにくくなる割合を次のパラィ ーターで表わす。

$$
\beta_{1}=\frac{P_{\mathrm{AA}}-P_{\mathrm{AB}}}{P_{\mathrm{AA}}}
$$

$P_{\mathrm{AA}}$ はホモポリマーのときのモノマー回収率 $Y_{0}(\mathrm{~A})$ に 等しい。1> $\beta_{1}>0$ のときには $\mathrm{A}$ モノマーの回収率はホ モポりマーより減少する。 $\beta_{1}<0$ のとき汇は共重合体の

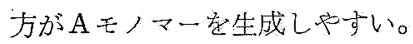

共重合体中に存在寸る $\mathrm{A}-\mathrm{A}, \mathrm{A}-\mathrm{B}$ 結合のモル分率は $F_{1} P_{11}, F_{1} P_{12}=F_{1}\left(1-P_{11}\right)$ であるから，熱分解达る $\mathrm{A}$ モ)マーの回収率は

$$
Y(\mathrm{~A})=F_{1} P_{11} P_{\mathrm{AA}}+F_{1}\left(1-P_{11}\right) P_{\mathrm{AB}}
$$

である*2。一方 $\mathrm{A}-\mathrm{B}$ 結合の数は $\mathrm{A}$ 連鎖の数と等しいか ら

$$
\begin{aligned}
& F_{1}\left(1-P_{11}\right)=\sum_{i=1}^{\infty} F_{2} P_{i}(\mathrm{~A}) \\
\therefore \quad & F_{1} P_{11}=F_{1}-\sum F_{2} P_{i}
\end{aligned}
$$

これらを (20) 式代代入して， $P_{\mathrm{AA}}=Y_{0}(\mathrm{~A})$ を用い，

$P_{\mathrm{AB}}$ を(19) 式により $\beta_{1}$ で表わせば

$$
\frac{Y(A)}{Y_{0}(\mathrm{~A})}=F_{1}-\beta_{1} \sum F_{2} P_{i}
$$

こ礼を(15) 式と比較して

$$
\beta_{1}=\theta_{1} / 2
$$

であることがわかる。

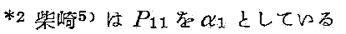

統計的共重合体の場合以は（17）式を用いて

$$
\begin{aligned}
& \beta_{1}=\frac{\theta_{1}}{2}=\frac{r_{1} f_{1}+f_{2}}{f_{2}}\left\{1-\frac{1}{F_{1}} \cdot \frac{Y(\mathrm{~A})}{Y_{0}(\mathrm{~A})}\right\} \\
& \beta_{2}=\frac{\theta_{2}}{2}=\frac{f_{1}+r_{2} f_{2}}{f_{1}}\left\{1-\frac{1}{F_{2}} \cdot \frac{Y(\mathrm{~B})}{Y_{0}(\mathrm{~B})}\right\}
\end{aligned}
$$

と表わせる。ゆ克に組成 $F_{1}, F_{2}$ のわかっている共重合 体より相対モ>マー収量を求めれば $\beta_{1}, \beta_{2}$ が定められ る。

$$
\text { さらに (21) 式より }
$$

$$
\frac{Y(A)}{Y_{0}(\mathrm{~A})}=F_{1}-\beta_{1} F_{1}\left(1-P_{11}\right)
$$

であるから

$$
P_{11}=1-\frac{1}{\beta_{1}}\left\{1-\frac{Y(\mathrm{~A})}{Y_{0}(\mathrm{~A})} \cdot \frac{1}{F_{1}}\right\}
$$

したがって

$$
P_{12}=\frac{1}{\beta_{1}}\left\{1-\frac{Y(\mathrm{~A})}{Y_{0}(\mathrm{~A})} \cdot \frac{1}{F_{1}}\right\}
$$

同様汇

$$
\begin{aligned}
& P_{22}=1-\frac{1}{\beta_{2}}\left\{1-\frac{Y(\mathrm{~B})}{Y_{0}(\mathrm{~B})} \cdot \frac{1}{F_{2}}\right\} \\
& P_{21}=\frac{1}{\beta_{2}}\left\{1-\frac{Y(\mathrm{~B})}{Y_{0}(\mathrm{~B})} \cdot \frac{1}{F_{2}}\right\}
\end{aligned}
$$

であるから， $\beta_{1} ， \beta_{2}$ が求められていれば，組成执よび相 対モノマー収量より $P_{11}, P_{12}, P_{21}, P_{22}$ が計算できる。.

\section{4. ガスクロマトグラフィー}

共重合体を熱分解して，その生成物をがスク口に導き 得られたパターンから，先の同定，組成の分析などを行 なら方法は，かなり広く行なわれるよらになった。この 方法は，もちろんホモポりマーの同定化も使光るから， 共重合体之混合物之の識別にも用いられている。ここで は実験の装置，方法特よび得られたピークの解析による 単なる同定と組成分析を行なっただけの子の悇き，主 として今まで述べてきた連鎖分布についての考察を含む るのをとり上げることにした。

Bombaugh $5^{6}$ はニチレン (E)ーアクリル酸メチル (MA) 叔よびェチレン(E)ーメタクリル酸メチル(MMA) の共重合体の混合物, ブロック（ほたはグラフト）共重 合体，ランダム共重合体をつくり，熱分解ガスクロの主 要なピーク面積 $A$ を測定し， IR で求めた組成 $F$ と此 較した。その結果前者については

$$
\text { メタノール指数 } \mathrm{MI}=\frac{A_{\mathrm{CH}_{3} \mathrm{OH}} / A_{\mathrm{MA}}}{\% F_{\mathrm{MA}}}
$$

後者については

主分解生成物指数 $\mathrm{MPI}=\frac{A_{\mathrm{MMA}} / A_{\mathrm{C} 8 \mathrm{E}^{\circ}-y}}{\% F_{\mathrm{MMA}}}$

を用いると，組成との間汇直線関係が得られ、ランダム とブロック拉よび混合物とははっきり異なる直線上に乗 ることが示された。第 1 図に後者の関係を示す。

Bombaugh ら² はさらに熱分解条件を検討し，エチ 


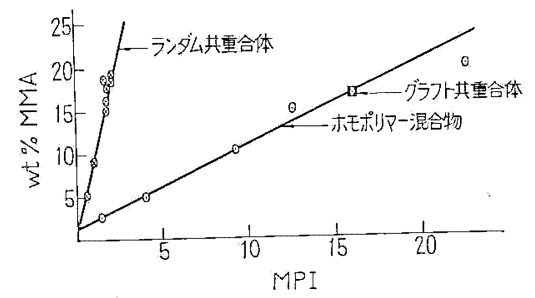

第 1 図エチレンーメタクリル酸メチル共重合体の 主分解告成物指数 (MPI) そ MMA 組成 との関係

レンー酶酸ビニル共重合体の組成を分析するには，なる ベく低温 $\left(300^{\circ} \mathrm{C}\right)$ で分解し，モノマーの回収率を良く するのが良いか，锤鎖分布を調べるにはより高温(800 $\left.{ }^{\circ} \mathrm{C}\right)$ で分解した方㚙良いといっている。

van Schooten と Evenhnis ${ }^{8)}$ はェチンン(E)-プロ ピレン (P) の等組成 $F_{\mathrm{E}}=F_{\mathrm{P}}=0.5$ の共重合体で, 完 全交互性（水素添加した天然ゴム), ブロック(二つのホ モポリマーの混合物)，種々の触煤を用いてつくったラ ンダム共重合体の熱分解ガスクロを比較し, ランダム共 重合体のパターソは交互性とブロックの中間のピーク 面積を示すことを明らかにした（第2図)。さらにプ ロピレンの連鎖に基く 2,4 ジメチルヘプタンピーク

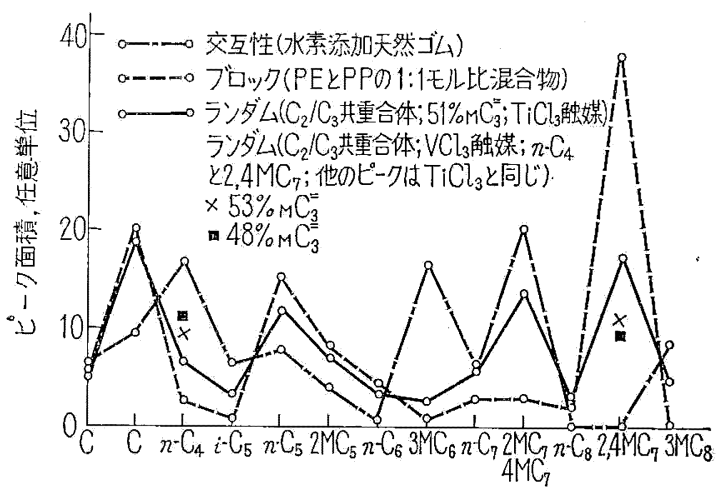

第 ${ }^{\mathrm{N}} 2$ 図 エチレンープロピレン共重合体の熱分解 ガスクロ

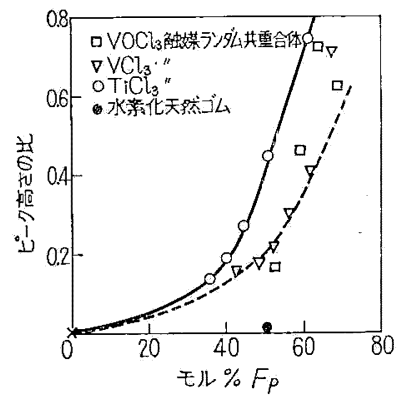

第3図エチレソープロピレン共重合体のピーク

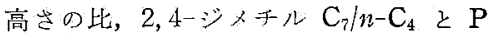
組成との関係 $\left(2,4 \mathrm{MC}_{7}\right)$ と $n$-ブタン $\left(n-\mathrm{C}_{4}\right)$ とを比較し，交互性の 水素添加天然ゴムでは前者は全くなく, 後者が大きいこ とから,これら二つのピークの高さの比が \% $F_{\mathrm{P}}$ に対 して一定の関係をもつことを示した（第 3 図）van Schooten らはさらに E-P 共重合体では $\mathrm{VOCl}_{3}$ 触媒を 用いたランダム共重合体では head-to-head の結合のた わにメチレン基が二つまたは三つつながった連鎖が生ず ることを指摘した。このことは 2,5-ジメチルへキサン

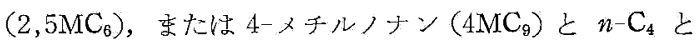
のピーク高さの比を $F_{\mathrm{P}}$ に対してプロットした曲線を， 他の触媒 $\left(\mathrm{VCl}_{3}, \mathrm{TiCl}_{3}\right)$ を用いたランダム共重合体执よ び水素添加した天然ゴム (交互性)の場合と比較すれば， 全く別の関係になることによって明らかにできる。なっ 彼らは $\mathrm{E}-\mathrm{P}$ 共重合体の組成分析性 $n-\mathrm{C}_{7} / 2 \mathrm{MC}_{7}+4 \mathrm{MC}_{7}$ のピーク高さの比を $F_{\mathrm{P}}$ にプロットした曲線（第 4 図） を用いるのがもっともよいと結論した。

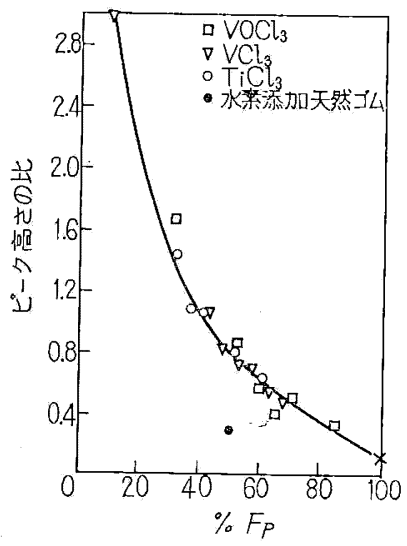

第[4図 エチレンープロピレン共重合体, ピー ク高さの比とプロピレン含量との関係

柴陭 ${ }^{5)}$ は組成の異なる低重合率のスチレン (St)ーアク リ口ニトりル (AN) および St-MMA のランダム共重合 体の熱分解ガスクロにより (23) 式を用いて $\beta$ を求め た。そ結果前者に対して $\beta_{\mathrm{AN}}=-2.25, \quad \beta_{\mathrm{St}}=0.21$, 後者に対して $\beta_{\mathrm{MNA}}=0.2, \beta \mathrm{St}=-0.3$ の値を得た。 $\beta$ が負になるのは共重合体の方がモノマーを生成しやすい ことを意味している。AN はホモポリマーでは環化や橋 かけしやすく，モノマーが生成しがたいが，St 単位が間 に入るとモノマーに切れる確沎が增すのである。な拈柴 崎はこのようにして求めた $\beta$ そ用いて種々の市販の St-AN 共重合体の $P_{11}, P_{22}$ 努求め, 共重合の理椧の示す $\left(1-P_{11}\right) F_{1}=\left(1-P_{22}\right) F_{2}$ が成立することを確め, 彼の理 諭の裹付仔を得た。

\section{5. 質 量 分 新}

質量分析による熱分解生成物の分析の例は，ガスク口 による分析よりははるか涹が少ないが，いくつか見出 


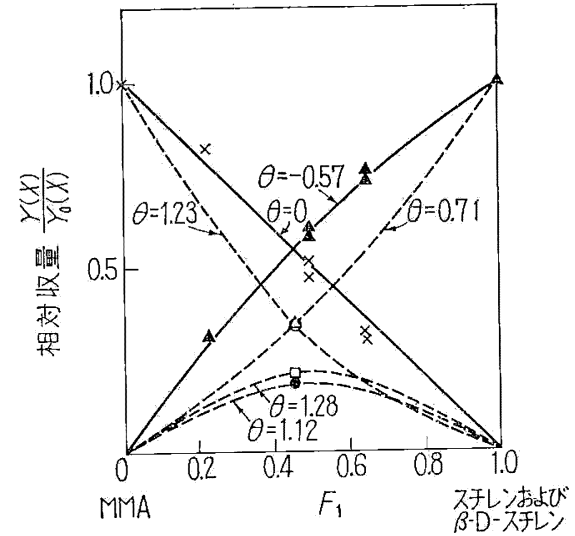

実驗值： ：スチレン， $:$ :MMA; $\triangle: \beta$-D-スチレン， $\mathrm{O}: \mathrm{MMA}, \square:$ : $\square レ ン, ~: \beta-\mathrm{D}-\mathrm{MMA}$

第 5 図メタクリル酸メチルとスチレン（理論: 実線) 特よび $\beta$ 一重水素化スヂレン（理論：

点線）と共重合体の相刘モノマー収.量

れる。この場合も分析方法は省略して，連鎖分布と関係 のある実験結果について述べる。

Wal1 ${ }^{4)}$ はスチレン (St)ーメタクリル酸メチル(MMA) 特よび $\beta$-重水素化スチレン ( $\beta$-D-St)-MMA 共重合体 の熱分解生成物意質量分析し, 很の理論に基いて $\theta$ を計 算した。その結果を第 5 図に示寸。St-MMA の場合ス チレンホモポリマーのモノマー回収率 $Y_{0}(\mathrm{St})$ は比較的 低いが, 共重合体になるとダイマー,トリマーなどの生が 抑总られるので,モノマー収率が良くなり $\theta=-0.57$ と いう負の值をとる。 MMA の方は $Y_{0}(\mathrm{MMA})$ が $100 \%$ であるから，共重合体になってもこの上らな增加はみら れず, $\theta=0$ となる。スチレンの $\beta$ 水素を重水紊で置換 寸ると，熱分解生成物が 4 種のモノマーを与兄る。スチ レンホモポリマーが多量の非モノマーを生成することを 考虑して，共重合によりモノマー/非モノマー此をシフ トすれば，スチレンに対して $\theta \mathrm{st}^{\prime}=1.28-0.57 / 2=0.99$ ， $\beta$-D-スチレンに対して $\theta_{\beta} \mathrm{D}_{\mathrm{St}}=0.71+0.57 / 2=1.00$ と. なる。 $\theta$ の値はいずれもほぼ 1 亿等しいから, ランダム 分解であり，元のモノマーの半分が回収されることを示 す。Wall はさらにスチレンーフマル酸ジメチル，スチレ ンークロトン酸メチルなどそついても同栐な計算を行な った。

Nencini ら ${ }^{9)}$ はエチレン（E)-プロピレン（P) 共重 合体のモデルとしてアイソタクチックな $\mathrm{PP}$, 水素添加 したポリインプレン（天然ゴム）PI を用いその熱分解 生成物を質量分析し，五十嵐3) の三角座標を用いて結果 を表示した。熱分解の主生成物は $n$-ブタン $\left(n-\mathrm{C}_{4}\right)$ 特よ び $n$-ペンタン $\left(n-\mathrm{C}_{5}\right)$ でこの量は共重合体中の $\mathrm{P}-\mathrm{P}$ 結合の数 (モル分率 $Y$ ), E-P および $\mathrm{P}-\mathrm{E}$ 結合の数(モ 儿分率 $Z$ ) 飞上って決委る。低圧 $\mathrm{PE}$ からの $n-\mathrm{C}_{4}$ 打 よび $n-\mathrm{C}_{5}$ の収率はごく少ないから， E-E 結合の数(モ

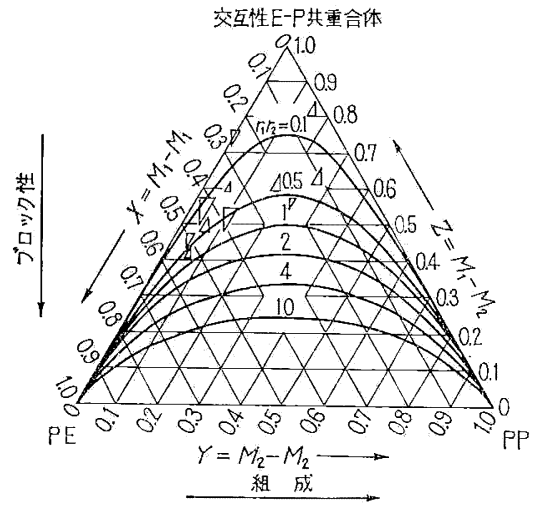

第 6 図 $\mathrm{E}-\mathrm{P}$ 共重合体組成とブロック性

ル分率 X)はこれらの収益関係ないるのと思われる。 PP および PI からの $n-C_{4}$ 拈よび $n-C_{5}$ の収量の測定 值を用いて, 共重合体からの収量 ( $\mu$ モル/g ポリマー) を表わせば

$$
\begin{aligned}
& Y\left(n-\mathrm{C}_{4}\right)=1.6 Y+117 Z \\
& Y\left(n-\mathrm{C}_{5}\right)=360 Y+29.7 Z
\end{aligned}
$$

となる。一方共重合体のプロピレンの組成を $F_{2}$ とすれ ば

$$
F_{2}=Y+\frac{1}{2} Z
$$

である。 $Y\left(n-\mathrm{C}_{4}\right), Y\left(n-\mathrm{C}_{5}\right)$ の実測値上り（27）式を用 いて計算した $Y, Z$ に上り（28）式で求めた $F_{2} か ゙$, NMR 飞より定めた值とよく一致することが確かめられ た。その結果を三角座標で示したのが第 6 図である。各 共重合体に対して $Y, Z, F_{2}$ について 3 回測定した結果 を小さい 3 角形で結び，実験誤差の範团を示してある。 三角形の中心がその共重合体の組成 䗆よびブロック性 （blockiness）を表わす点と考光てよい。尔た第 6 図より 反応性比の積 $r_{1} r_{2}$ が決定される。この結果では $F_{\mathrm{P}}=$ 0.25 0.65 亿打いて $r_{1} r_{2}$ の值は活潘一致している。 Nencini $5^{103}$ 怯 E-P 共重合体の熱分解生成物中に $n-\mathrm{C}_{5}$ と $n-\mathrm{C}_{4}$ が生ずる理由を，分解が第三級 $\mathrm{C}$ 原子から始を り，分子内飞 連鎖移動が起こる機構によって説明して いる。

\section{6. 打わりに}

以上共重合体の熱分解により，その組成执よび連䥊分 布飞関する知見を得る方法の原理について解説をした。 実をいらと，共重合の理諭的発展に比べると熱分解法に よるその裏付けの方が発達が痋れている。しかも組成の 分析てらば IR の方が簡便であるし，連鑽分布を調べ るには NMR の方が，常に可能ではないにしても，理論 的炕すっきりしている。しかし熱分解によってモノマー また㤝その他の生成物を捕觉ることは上り直接的である し，他の方法に対して根抛を与えることにるなるので軽 
視するわ怆はいかない。

本稿を書くにあたり初めは，示差熱分析批よび重量熱 分析火よる共重合体の確認と組成の分析, 熱分解反応速 度の問題などにもふれるつもりであった。しかし与えら れた時間と紙数をはるかてこえてしまったので今回はこ こで打ち切ることにした。

\section{交献}

1) H. J. Harwood: Angew. Chem., 77, 405 (1965)

2) H. J. Harwood, W. M. Ritchey: Polymer Letters, 2, 601 (1964)

3) S. Igarashi: Polymer Letters, 1, 359 (1963)

4) L.A. Wal1: N.B.S. Circular, No. 525, 239
(1953); L. A. Wall, J.H. Flynn: Rubber Chem. Techn. 35, 1157 (1962); L. A. Wall; Anal. Chem. of Polymers (ed. G. M. Kline), part II, Chapter V, 1962

5）柴崎芳夫：高化，21，125（1964）

6) K.J. Bombaugh, C.E. Cook, B.H. Clampitt; Anal. Chem. 35, 1834 (1963)

7) K. J. Bombaugh, B.H. Clampitt: J. Polymer Sci., A3, 803 (1965)

8) J. Van Schooten, J.K. Evenhuis: Polymer, 6, 561 (1965)

9) G. Nencini, G. Giuliani, T. Salvatori: Polymer Letters, 3, 483 (1965)

10) G. Nencini, G. Giuliani, T. Salvatori: Polymer Letters, 3, 749 (1965)

\section{バックナンバ一在庫紹介}

下表に在庫分の巻, 号, 頒価を揭げ亲す。購入希望の

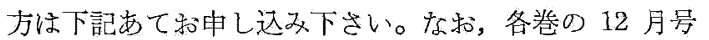
にその年発行さ机た分の総目次が揭載してあります。

東京都干代田区神田須田町 $2-11$

電話 東京 (253) 8703 (直) (251) 5545 高分子学会会員課バックメンバー係

高 分子

\begin{tabular}{|c|c|c|}
\hline 巻 & 通巻 (号) & 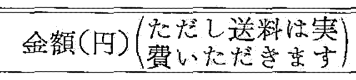 \\
\hline 1 & (1) (7) & (120) \\
\hline 2 & $(1) \sim(12)$ & $(100)$ \\
\hline 3 & (1), (2), (4) (12) & $(100)$ \\
\hline 4 & (3), $37 \sim 4,041 \sim 45$ & $(100)(150)$ \\
\hline 5 & $46 \sim 51,55,57$ & \\
\hline 6 & $60,63 \sim 69$ & \\
\hline 7 & $70,72,73,75 \sim 81$ & (150) \\
\hline 8 & $\begin{array}{l}82,84 \sim 87,89,90, \\
92,93\end{array}$ & \\
\hline 9 & $\begin{array}{l}96,100 \sim 102,104, \\
105\end{array}$ & 100 号 (300), あとは (150) \\
\hline 10 & $106,108 \sim 117$ & 106 号 (300), 屯とは ((50) \\
\hline 11 & $\begin{array}{l}118,120 \sim 125,127 \\
\sim 129\end{array}$ & 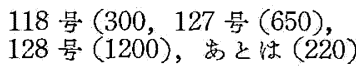 \\
\hline 12 & $130 \sim 141$ & $(220)$ \\
\hline 13 & $142 \sim 153$ & $(220)$ \\
\hline 14 & $154 \sim 165$ & 163 号 (850), 㐫とは (220) \\
\hline 15 & $166 \sim 169$ & $(220)$ \\
\hline
\end{tabular}

高分子交献集

\begin{tabular}{c|c|c}
\hline 年 & 号 & 金 額 (月) \\
\hline 1954 & $2 \sim 6$ & 150 \\
1955 & $7 \sim 1$ & 150 \\
1956 & $14 \sim 21$ & 150 \\
1957 & 22,24 & 150
\end{tabular}

高分子化学

\begin{tabular}{|c|c|c|}
\hline 巻 & 号 & 金 額（円） \\
\hline 9 & $86,8789 \sim 91$ & (200) \\
\hline " & 88,92 & $(100)$ \\
\hline 10 & $93 \sim 104$ & $(100)$ \\
\hline 11 & $105 \sim 116$ & $(100)$ \\
\hline 12 & $117 \sim 119$ & $(100)$ \\
\hline$"$ & $122 \sim 128$ & $(100)$ \\
\hline 13 & $129 \sim 140$ & 133) 号 (200) あとは (100) \\
\hline 14 & 143,145 & $(100)$ \\
\hline$"$ & $147,148,150,152$ & $147 \cdot 150$ 号 $(200)$ 岕とは 100 \\
\hline 15 & $158 \sim 164$ & $\begin{array}{l}164 \text { 号 } 250), 161 \cdot 163 \text { 号(130), } \\
162 \text { 号(250), あ とは 100) }\end{array}$ \\
\hline 16 & $165 \sim 167$ & 165 号 (250), むとは (100) \\
\hline 17 & $183 \sim 188$ & $183 \cdot 186$ 号 (250)あとは(130 \\
\hline 18 & $191,195,200$ & 201 号 (250)，ぬとは 130) \\
\hline 19 & 201,202 & 210 号 (250) あとは (130) \\
\hline " & $209 \sim 212$ & 213(219号(250), 焉とは(130 \\
\hline 20 & $213 \sim 215,218 \sim 222$ & $225,228,231,234,240,24$, \\
\hline 21 & $225 \sim 227,231 \sim 236$ & $\begin{array}{l}246 \sim 249 \text { (250)，あとは } \\
(130)\end{array}$ \\
\hline 22 & $237 \sim 249$ & \\
\hline
\end{tabular}

海外高分子研究

\begin{tabular}{c|c|c}
\hline \hline 巻(年) & 号 (通巻潘号) & 金 \\
\hline 1 & 1,6 & 150 \\
2 & $2 \sim 6$ & 150 \\
3 & $1 \sim 6$ & 150 \\
4 & $1 \sim 6$ & 150 \\
5 & $2,4 \sim 6$ & 150 \\
6 & $2,4,9$ & 150 \\
7 & $1,4,1$ & 150 \\
$(1961)$ & $(54)$ & 200 \\
$(1962)$ & $(55) \sim(65)$ & 200 \\
$(1963)$ & $(68) \sim 78(78)$ & 200 \\
$(1964)$ & $(79),(81) \sim(86)$ & 200 \\
$(1965)$ & $(87) \sim(102)$ & 200 \\
$(1966)$ & $(103)$ & \\
\hline
\end{tabular}

